\title{
PETROLEUMSCAPE AS BATTLEGROUND
}

\author{
Pladjoe, Pearl in the Crown of the Bataafsche \\ Petroleum Maatschappij (BPM/Shell) in the \\ Dutch East Indies
}

\author{
Ben de Vries
}

Oil fields can easily turn into battlefields. This happened more than once in the former colony of the Dutch East Indies (Nederlands-Indië, now Indonesia) in the turmoil of the 1940s, when Japanese, Dutch, Allied, and Indonesian forces fought fierce battles over the control of local oil facilities - with good reason, because in the 1940s the Dutch East Indies was one of the world's biggest oil exporters. Centered on the oil industry city of Plajoe, this portion of the global petroleumscape, ${ }^{1}$ a multilayered network of spaces made possible by petroleum and facilitating its flow, was designed to support a country on the other side of the world. It was then reshaped by war and revolution, in the context of changing global actors. This chapter tells a largely unknown story about the construction, destruction, and reconstruction of the petroleumscape in what is now the province of South Sumatra in Indonesia. It is a story of how oil fields can become battlefields and of how even in peacetime a petroleumscape is shaped by attempts to protect and defend sources of wealth and power.

In the mid-1880s, oil was discovered at Telaga Said I, at a shallow depth of 400 feet in a thick jungle in the northern part of the huge island of Sumatra. In the mid-1890s, better quality oil was found in a swampy area in southern Sumatra near Peraboemoelih (Figure 3.1). As a result, nearby Palembang, an ancient city with harbor facilities, quickly mushroomed into a vibrant oil industry city. At the same time, the small kampoeng of Pladjoe (Plaju), about $8 \mathrm{~km}$ further along the Moesi (Musi) River, became a spider in an enormous web of petroleumrelated infrastructures. In 1907, the Royal Dutch Petroleum Company or Koninklijke Nederlandsche Maatschappij tot Exploitatie van Petroleumbronnen in Nederlands-Indië (1890) formed a subsidiary called the Batavian Oil Company or Bataafsche Petroleum Maatschappij (BPM/Shell) and built at Pladjoe the largest, most productive, and modern refinery in Southeast Asia at the time. The scale of operations grew and BPM planned a comprehensive oil company town with administration buildings, refineries, pipelines, roads, railroad tracks, and jetties for mooring tankers. This chapter examines how BPM and the municipality of Palembang, the main oil actors in this region, spatially and economically planned its huge industrial oil footprint at Pladjoe and safeguarded its facilities against brutal intrusions and destruction during the Japanese occupation of the Dutch East Indies during the Pacific War (1942-1945) and Indonesia's struggle for independence (1945-1949). 


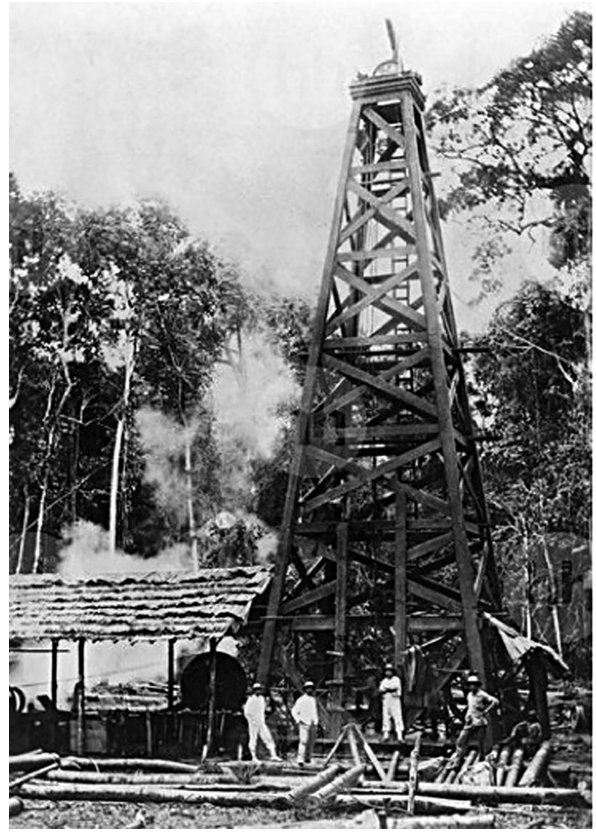

FIGURE 3.1 Oil drilling tower in Soeban Djerigi, near Peraboemoelih, South Sumatra, 1915. Source: Collection Spaarnestad Photo, Haarlem.

\section{Pladjoe: The Pearl in BPM's Crown}

Pladjoe provides a case of how oil fields can change hands and suffer destruction, leading to shifts in the petroleum networks in which they are located, but then these sites can be rapidly rebuilt and continue to function. To understand the development of the petroleumscape in Pladjoe, it will be helpful to consider a brief history of Dutch oil exploitation in Indonesia before examining not only architecture and the built environment, but also oil's representations and social meanings. The second part of this chapter addresses how the existence of the petroleumscape encouraged both military conflict and efforts at protection.

Oil production in the Dutch East Indies began with a rich Dutch farmer's son, Aeilko Jans Zijlker, who went to the Indies to find his luck after an unhappy love affair. Zijlker, administrator of the East-Sumatra Tobacco Company, discovered oil first in North Sumatra. What he found was a kind of oil seep, of rather poor quality, good only for lamp oil. After negotiating royalties with the owner, the Sultan of Langkat, in 1883 Zijlker obtained the concession of the area and permission to drill. ${ }^{2} \mathrm{He}$ was incredibly lucky as the results proved to be much better than expected. After quickly assessing its potential, the Dutch King William III named the company the Royal Dutch Petroleum Company or Koninklijke Nederlandsche Maatschappij tot Exploitatie van Petroleumbronnen in Nederlandsch-Indië. This freestanding company was officially established on June 16, 1890, with a large financial guarantee of about US $\$ 360,000$ (value at the time). ${ }^{3}$ As a result of this amazing success, $\mathrm{Zi}$ jlker was sent to do more exploration and drilling around his oil kampoeng, but his luck did 


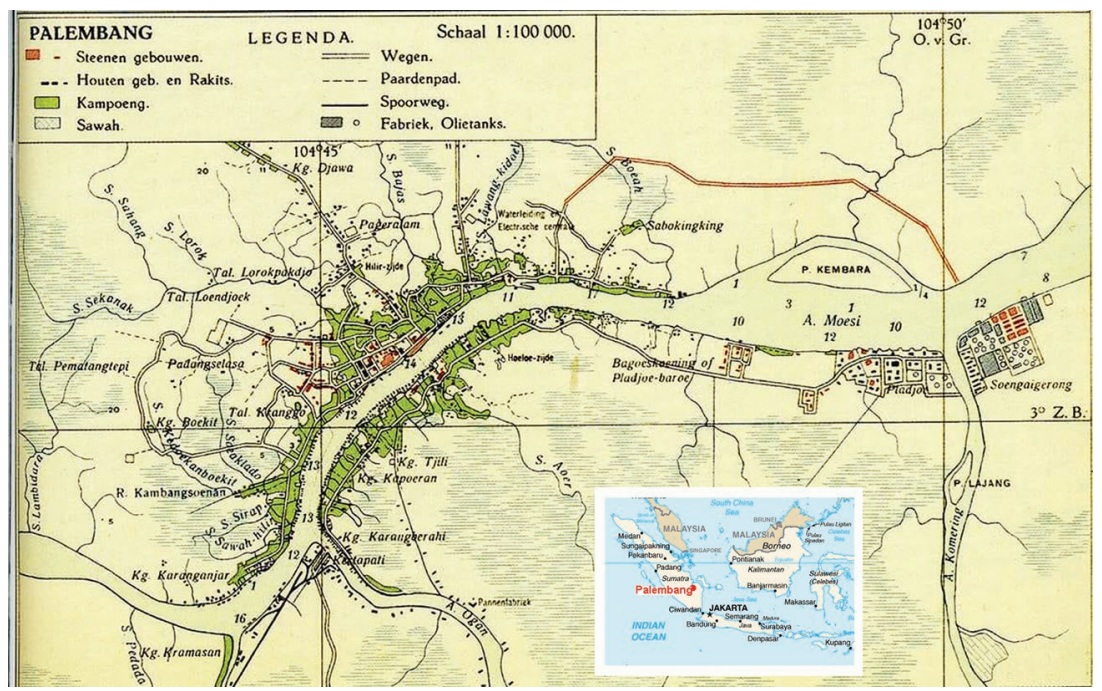

FIGURE 3.2 General map oriented to the northwest, of Palembang and environs, in 1938, with Kertapati (left-lower), Pladjoe and Soengei Gerong (right-middle), and Bagoes Koening (middle), all on the south bank of the Moesi River. Source: J. R. Van Diessen, Comprehensive Atlas of the Netherlands East Indies.

not last and he died in December of the same year. Nevertheless, this site would become the origin of one of the biggest multinationals of the world today: Royal Dutch/Shell Group, the name reflecting a 60:40 Dutch-British ownership structure. ${ }^{4}$

When oil was found in southern Sumatra, it was experienced Jan Willem IJzerman, head of the French-owned Moeara Enim Petroleum Company, who stepped in first and invested in a site near the ancient port city of Palembang, capital of the province of South Sumatra. ${ }^{5}$ Palembang, founded in 683, saw a period of general prosperity in the later seventeenth century as an important exporter of pepper and tin, and it was a major river transport hub, strategically located along the Malacca Straits, near Singapore and Batavia (Jakarta). All over the world at that time, oil production and transport relied heavily on water. ${ }^{6}$ From Palembang harbor to the open waters of the Bangka Straits was about fifty nautical miles. The waterfront city, known as "Venice of the Far East," stretched along both sides of the 750-km-long muddy Moesi River (Figure 3.2). The main economic and political hubs, like the Kraton-the former sultanates' fortified palace and its surroundings - could be found on the eastern bank, called the Hilir-side (Ilir) ("downstream"). On the western, "upstream" riverbank or Hoeloe-side (Ulu), about $8 \mathrm{~km}$ from the center of Palembang, IJzerman established an oil refinery in 1897. At that time, the place was nothing more than a small kampoeng carrying the local name Pladjoe, although at this strategic river location in the eighteenth and nineteenth centuries there had been local wooden palisades forming a defensive barrier. There was no overland transport between Pladjoe and the city center of Palembang, as there were no bridges yet. People had to take a ferry. Hence, Pladjoe was located across the river, geographically proximate but socially distant from the city, and it transformed steadily into a well-organized Western enclave-a symbol of modernity and European might. ${ }^{7}$ 


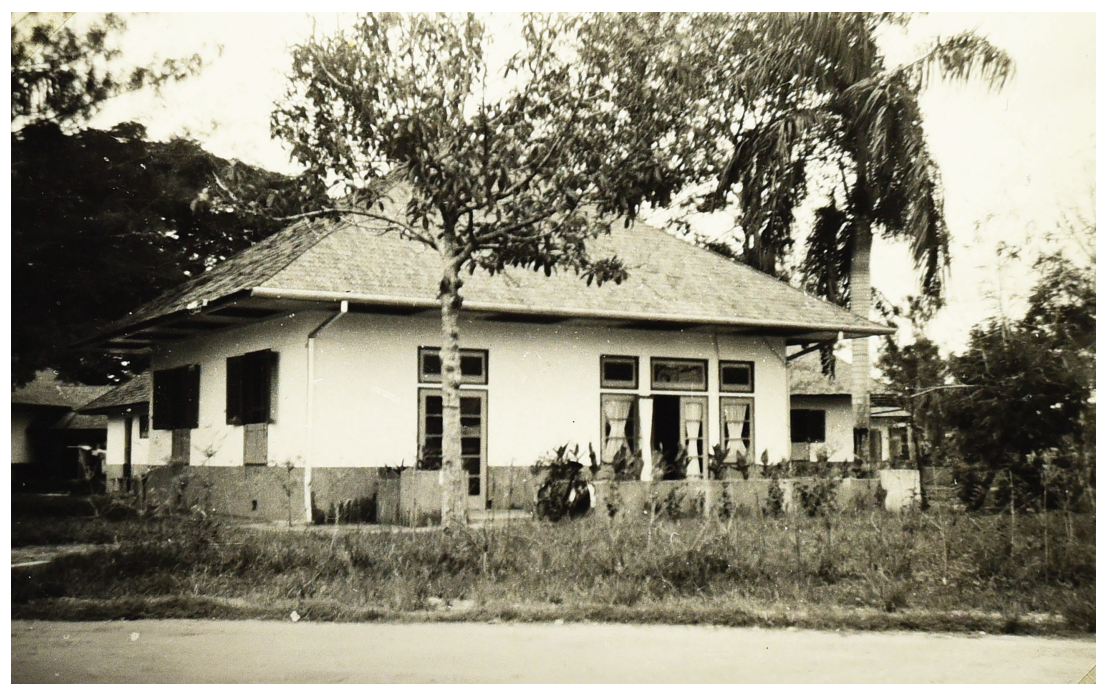

FIGURE 3.3 Private house of the Engelberts family. Mr. Engelberts was a technical manager of the cracking installation-a unit used to break hydrocarbons-at Pladjoe, 1947. Source: Collection Mieke Engelberts.

The refinery on the west bank of the mouth of the tributary produced marketable secondary products which could be efficiently transported by oil tankers from the refinery's jetty to Java, Singapore, Europe (through the Suez Canal), the US, or Japan (especially to Yokohama). The refinery received an abundance of crude oil from the rich oil fields of Talang Djimar, Peraboemoelih, and Moearaenim. Half of the Indies' oil production was produced at this refinery, especially aviation crude.

On the west side of the sprawling production refinery-which took up about $1,500 \times$ $2,000 \mathrm{~m}$ - BPM created an ancillary petroleumscape in the form of a compound with houses for executives, employees, and workers (Figure 3.3). Most of these stand-alone villas were grouped in blocks of eight or ten and were almost identical in colonial design, varying only slightly depending on the rank of the employee. ${ }^{8}$ Most of the houses had a driveway, a garden, a front veranda and a large overhang that provided protection from the tropical sun. The houses were well ventilated and each one had an annex at the back with a separate bathroom, a kitchen, and rather simple rooms for indigenous people employed as servants. The European employees' houses were situated along palm-bordered avenues and featured impeccably manicured lawns, easily accessible by private cars. This neat and orderly area was continually being extended to the south and southwest. The streets had no names, only numbers. An address, for example, was "4th Street" and "House 122."

The compound, with its almost rectangular grid plan of about $500 \times 1,000 \mathrm{~m}$, was fully equipped with all kinds of facilities. BPM had its own administration building, hospital, post office, hotel (pasanggrahan), bakery, shop, and pasar (Figures 3.4-3.6). There was a church, mosque, European primary schools, a Chinese primary school, library, a clubhouse or "soos" with cinema and theater, sports fields for hockey and tennis, and of course, there was a swimming pool. ${ }^{9}$ To this day, one can see this Dutch legacy and enjoy the green and spacious compound and the striking tropical modernity of its so-called Indies 


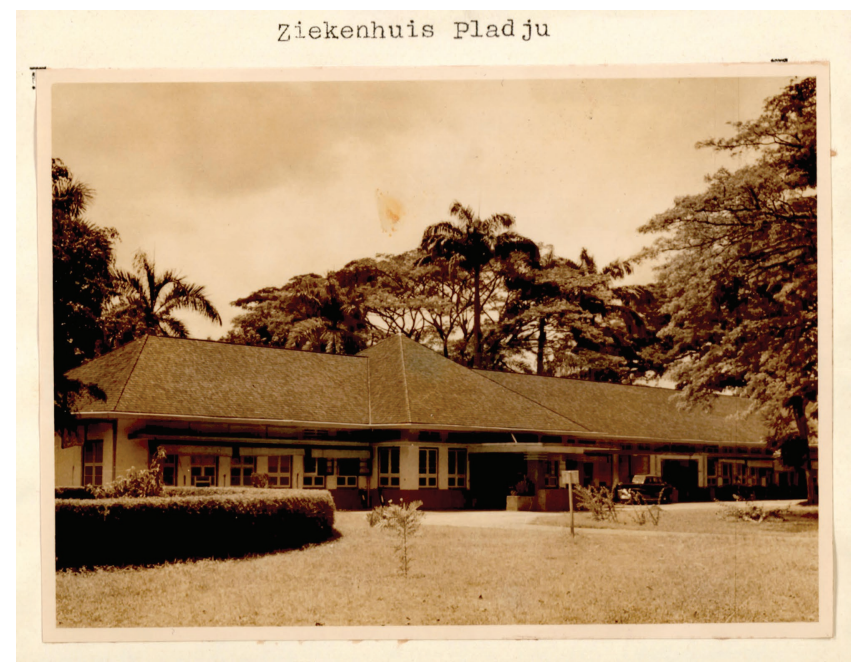

FIGURE 3.4 BPM hospital at Pladjoe. Source: Expatriate Archive Centre, The Hague.

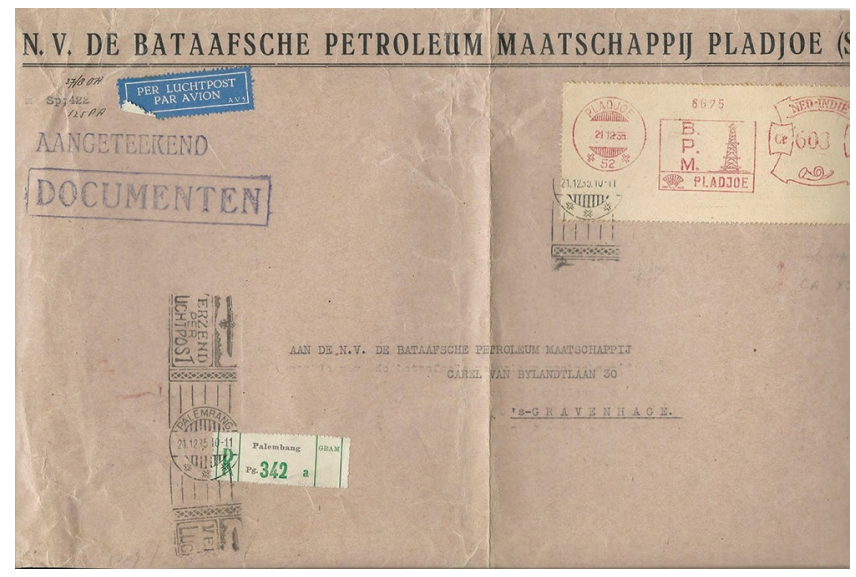

FIGURE 3.5 Postage stamp of Pladjoe, May 20, 1934. Source: Author.

Architecture - a hybrid mix of a Dutch modern style adapted to the tropical climatedespite the fact that some of the colonial buildings are dilapidated. Most of the original buildings in this exclusive settlement still serve the same function as before, but are owned and used by high-ranking staff of Pertamina, the Indonesian state-owned oil company.

In 1924, BPM launched a three-hour-long "Bataafsche Petroleum Film" made by the most well-known Dutch filmmaker of the 1920s, Willy Mullens, in cooperation with C. W. A. Van Bergen, who worked for the Bataafsche marketing organization. This carefully planned propaganda film, one of the earliest moving images of BPM employees in the Dutch East Indies, depicted the modern colonial society in which BPM fully participated. ${ }^{10}$ During the official launch of the documentary film on 18 June at the majestic concert hall 


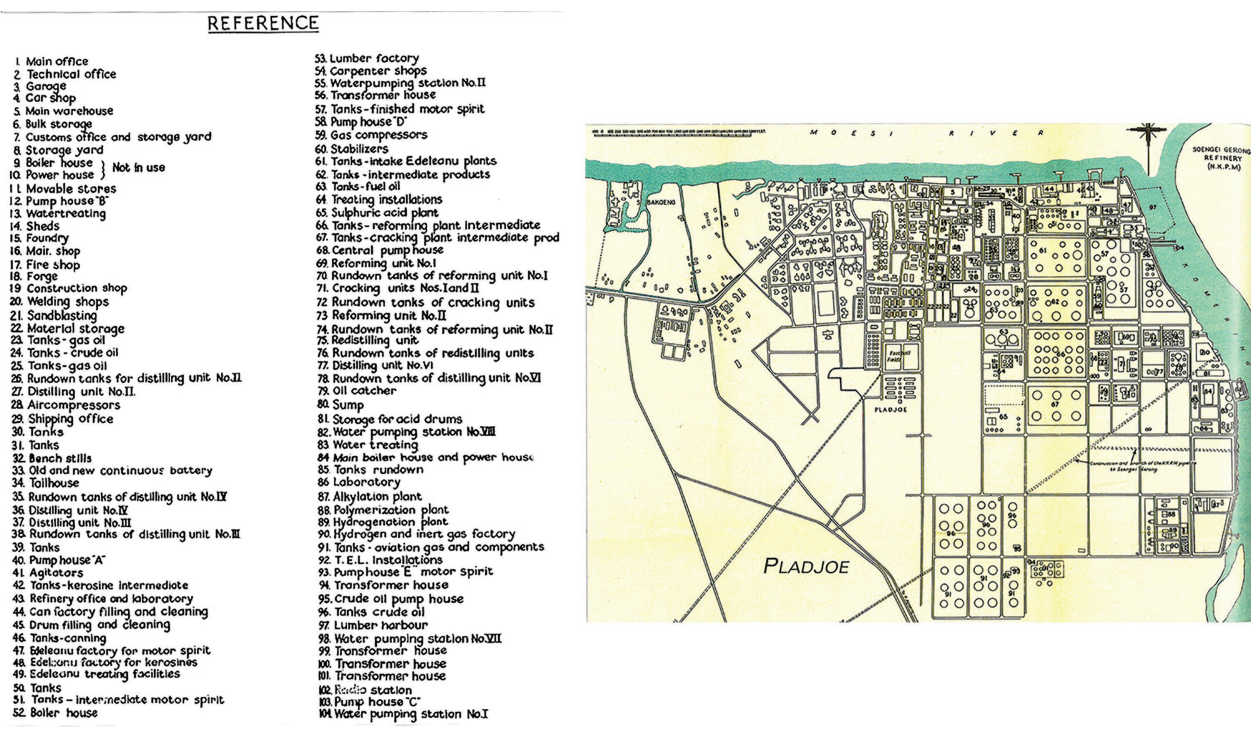

FIGURE 3.6 The Pladjoe compound, July 1945. This map is based on BPM maps dating from 1936 and 1940. The reference shows only the technical installations. Source: J. R. Van Diessen, Comprehensive Atlas of the Netherlands East Indies.

of the Kurhaus in Scheveningen, near The Hague, BPM Managing Director Dr. August Philips provided a welcoming speech to the crowd of 1,600 invitees, among them many important representatives from the business community, the government, the diplomatic corps, and the press. Philips was very proud of the company and stressed the positive impact of oil on the lives of people of the Indies. The film documented company activities with the aim of gaining public support. After the premiere, the corporate film toured the Netherlands and was shown at various societies and associations, and also abroad.

Outside white-collar neighborhoods of gloriously shaded streets and lots, the urban space of the colonial society was more differentiated and divided by ethnicity, race, and class. The socio-ethnic categorization was reflected in the spatial layout of the refinery town. In Pladjoe, at the beginning of the 1920s, there were about 250 (475 in 1929) European employees and about 4,500 local Indonesian and Chinese or Asian workers (Figure 3.7). ${ }^{11}$ Among the contract laborers, 80 percent came from South Sumatra. European residential quarters were situated in the western part of the compound, at quite a distance from industrial noise and pollution. Europeans were also accommodated in another salubrious BPM housing complex called Bagoes Koening (or Pladjoe-baroe: New Pladjoe), a little further west of Pladjoe. Groups of indentured laborers (or "free coolies," a term that at the time was not recognized by the Dutch as a racial slur) stayed in barracks (tangsi) with vernacular-style roofs and a common kitchen and bathroom, and in so-called koelie bangsals and in kranie houses, located in the south part of the compound.

In order to facilitate the steadily growing petroleum industry and to improve the rather low standard of living, the municipality of Palembang started to construct new ancillary structures and assets, like asphalted public roads, railways, ports, and two airfields. One of the airfields was in Talangbetoetoe, $15 \mathrm{~km}$ northwest of Palembang, and the other one was a secret military airfield, $75 \mathrm{~km}$ west of Palembang, near Peraboemoelih, called P2, which was still under construction in 1941. It was perfectly 


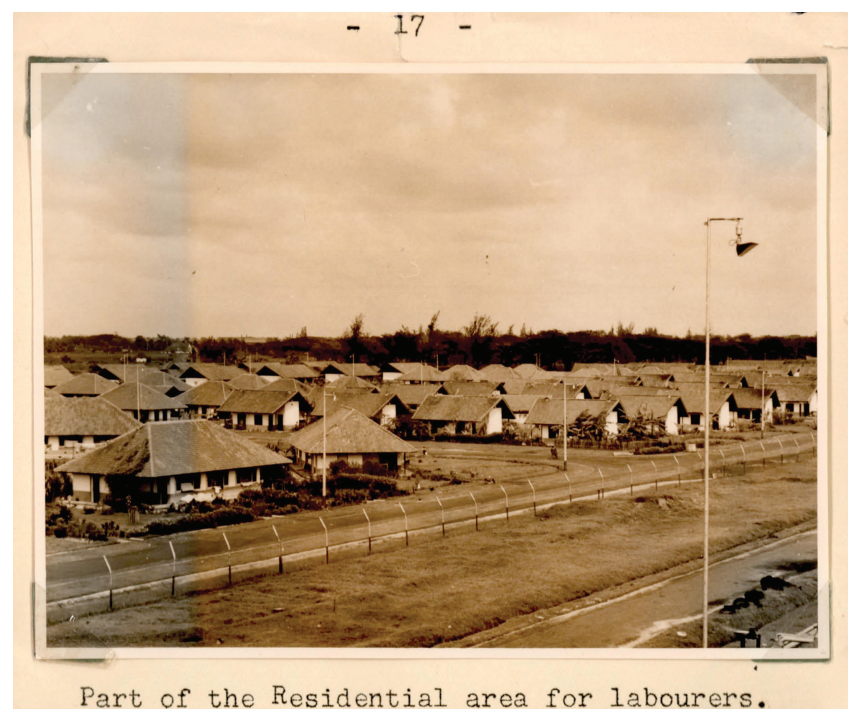

FIGURE 3.7 Part of the residential area for Asian laborers of BPM at Pladjoe. Source: Expatriate Archive Centre, The Hague.

camouflaged by the dense tropical forest and not known to Japanese troops at the time of the invasion.

An important stage of the expansion can be seen in the municipal traffic commission's implementation of a new town plan in 1937, designed by the Dutch architect Thomas Karsten, with help of urban planner Hans Lüning. Land was reclaimed from rivers and used to build new public housing, inland transport systems, a ring road, several bridges over the Moesi River, and the Wilhelmina Bridge (1939) over the Ogan River, replacing the river ferry. This important arch bridge connected both oil refineries from the eastern to the western bank, where the new Kertapati railway station (1939) and the coal harbor were located. On a regular basis in the late 1920 s, ocean steamers with a maximum loaded draft of $7 \mathrm{~m}$ navigated the river. Meanwhile, the new and continuously expanding oil industry led to the rapid influx of newcomers and a subsequent population increase in Palembang. ${ }^{12}$ Also, a new European residential quarter was begun on the higher grounds of Talang Semoet, $1.5 \mathrm{~km}$ west of the Kraton. The population rose from 50,703 people in 1905 to 73,726 in 1920, and 108,000 in 1930, of which 2,000 were Europeans and 16,000 Chinese. The population would eventually rise to about 140,000 in 1940 and to 208,379 in 1951 .

The booming oil industry not only had an enormous influence on the socioeconomic structure of the city, but on the whole region as well, and in a way that was opportune for the oil industry. More than thirty-five oil-mining concessions in the area needed a complete infrastructural network of iron pipelines to connect hundreds of drill towers, oil pumps, and storage tanks, which subsequently transformed the existing semi-urban spatial landscape into an industrial one. They all stand as material witnesses to the invasiveness of petroleum. Nothing remained like it was. Extraction, refining, transformation, and the consumption of petroleum all required new spaces, and the expensive and extensive petroleum infrastructure made a huge impact on the landscape, rivers, nearby sea, city, and buildings. Eventually, these spaces were all connected to this single commodity and its group of industrial players. In addition, BPM built a road network, a vivid symbol of 
modernization, and forty-two schools throughout the southern province before the $\mathrm{Pa}-$ cific War. ${ }^{13}$ Such an extended petroleumscape with various oil actors required multiple headquarters for administration and supervision, like the one in the political heart of Batavia, designed in a modernist colonial style in 1937 by Dutch architect Thomas Nix. It did not reference the global head office of BPM/Royal Dutch Shell in The Hague, which was both hypermodern and traditionalistic, inspired by the Renaissance and by seventeenth-century Dutch Classicism, built in 1917 by the well-known architects the Van Nieukerken brothers.

Most important, a network of BPM petrol stations extended across Sumatra. According to a 1929 Shell road map, there were in total 185 fuel stations strategically positioned on the island, including seventy-one in the South Sumatra region, two in Palembang, one in Djambi, and one in Pladjoe itself (Figures 3.8 and 3.9). Although most of the stations were rather basic shed-type gas stations, they had a recognizable corporate standardized design: a combination of a BPM sign with typical lettering and a Shell pecten logo, a humble pump island, and prefabricated steel panels.

Just like in the Netherlands, the gas stations handed out free road guides, which served as public relations material produced by the "Handelszaken" (Commercial Affairs) unit of BPM. The 1929 guide was covered with two slogans: on the left, "Shell motor oil worth every drop" (Elke Druppel is van Waarde), and on the right, "Shell autoline for balance and energy" (voor Evenwichtigheid en Arbeidsvermogen). Of course, these representations promoted petroleum usage and driving. BPM/Shell used the same advertising strategies throughout the world. In this way, petroleum imaginaries shaped citizen behavior and slowly oil became a heroic partner in creating contemporary society and identity. ${ }^{14}$ Oil became central to modern life and was taken for granted in a way that made it almost invisible despite its ubiquity.

\section{Monopoly of Mighty BPM}

Further north, around the residency of Djambi (Jambi) in Central Sumatra, were situated the oil fields and small distillation companies of Tempino, Kenali Asam, Badjoebang, Betoeng, and Mangoendjadja. The fields were owned by the Nederlands Indische Aardolie Maatschappij (NIAM), a public-private partnership between BPM and the Dutch East Indies government, set up in 1921. This joint venture was an economic novelty. It was the first time the government became an actor through shares in the Sumatran oil industry. As was usual in these mixed enterprises, the private partner, BPM, provided the operational management and disposed of the production.

The actual refining process did not take place in Djambi, but in Pladjoe. ${ }^{15}$ Starting in 1935, and with help of Persian pipe drillers, oil was transported from Tempino to Pladjoe through a pipeline for $270 \mathrm{~km}$ through hilly country covered by dense forests, along rice fields, intersecting many watercourses. In 1933, partly with NIAM's support, roads and an airport were built and the city was linked to a railroad. In 1936, a road was opened between Palembang and Padang by way of Djambi. And in 1938, Djambi accounted for about 14 percent of the total East Indies oil production. ${ }^{16}$

BPM feared and had to cope with increasing competition from the American Standard Vacuum Oil Co. (henceforth Stanvac, today ExxonMobil), working through an affiliate: the Nederlandsche Koninklijke Petroleum Maatschappij (NKPM). Although the Dutch Indies government tried to keep foreign oil companies outside the colony through the Mining 

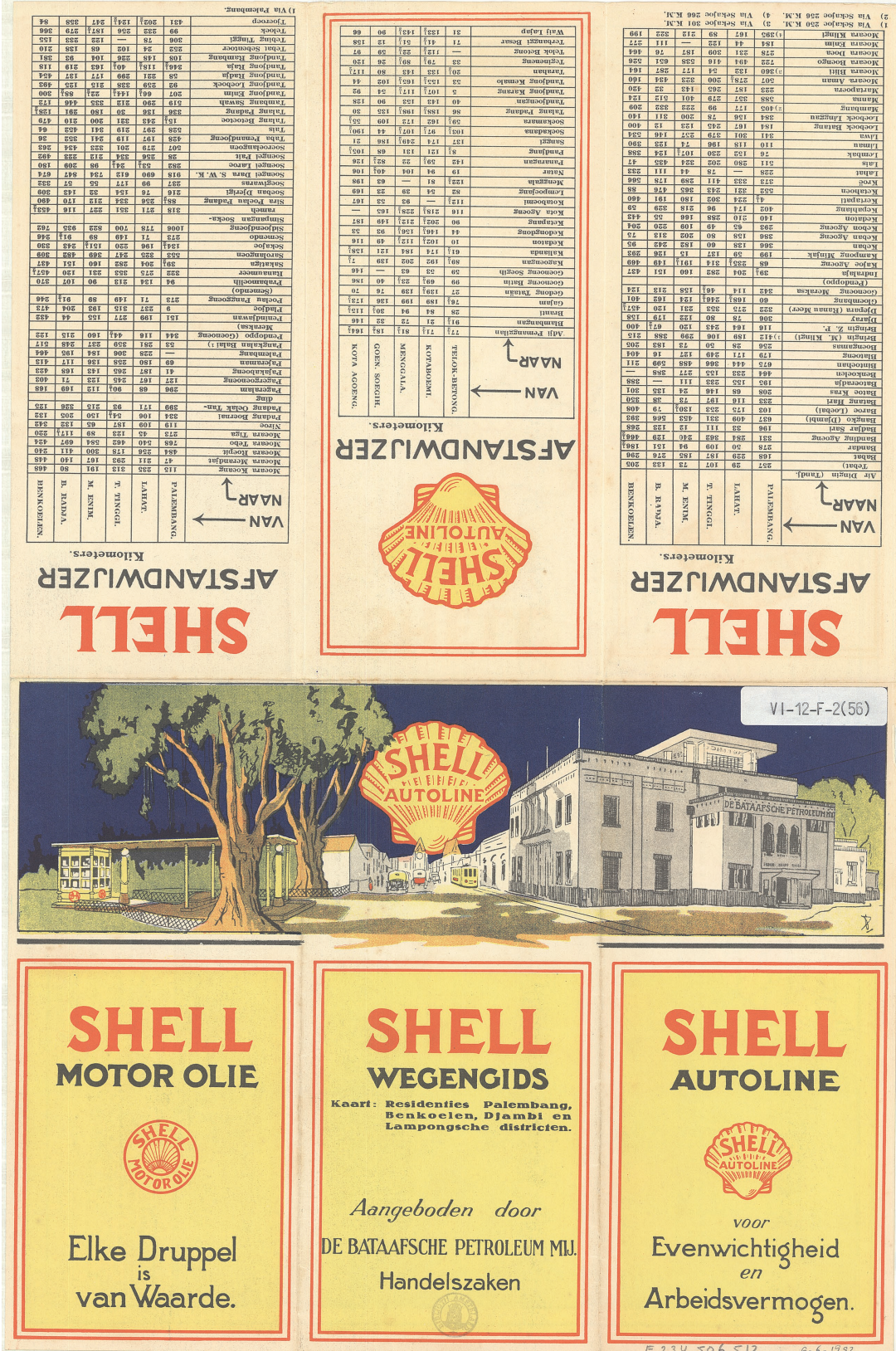

FIGURE 3.8 Shell road guide (Wegengids, 1929) with a map of the residencies of Palembang, Benkoelen, Djambi, and the Lampongsche districts. Source: Bijzondere Collecties, University of Amsterdam.

Act, Stanvac struggled to compete with BPM. Hence, they started in 1912 to operate their own refinery at Soengei Gerong, directly opposite Pladjoe, on the east side of the Komerine River. ${ }^{17}$ It developed into the second-largest oil facility in the Asian region, receiving 3,500 barrels of crude per day by pipelines from the fields of Talang Akar. ${ }^{18}$ The plant at 


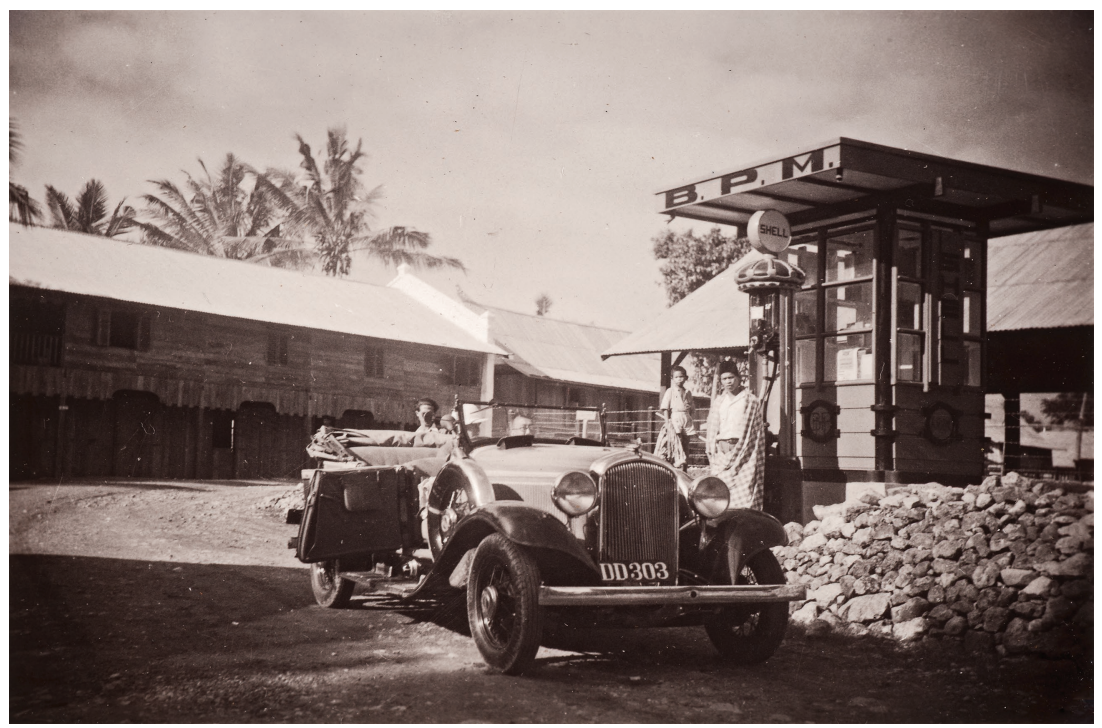

FIGURE 3.9 Private luxury car being fueled at BPM station. Over time, oil influenced lifestyles and became an everyday necessity. Source: Collection Nationaal Museum van Wereldculturen. Coll. no. 60037451.

Soengei Gerong challenged BPM's control over global flows of oil. In 1930, another serious rival emerged on stage: Caltex (today Chevron). They also worked through a subsidiary, the Netherlandsch Pacific Petroleum Maatschappij (NPPM), and secured extensive exploration concessions in Central Sumatra and on the Riau Islands. ${ }^{19}$

BPM, operating exclusively in the Dutch East Indies, had quite a strong position, managing large export refineries and controlling an enormous distribution network across the archipelago. ${ }^{20}$ Apart from the ones on Sumatra, there were refineries on the island of Java in Tjepoe and Wonokromo. The island of Borneo (now Kalimantan) had a huge refinery in Balikpapan, a few oil fields in Tandjoeng, and a strategic oil enclave on the island of Tarakan. Further to the east, there were concessions on the Moluccan island of Ceram. Finally, BPM held 40 percent of the shares in the Nieuw Guinee oil fields of Klamono and Mogoi-Wasian. The other 60 percent were managed together by the N.V. Nederlandsche Nieuw Guinee Petroleum Maatschappij (NNGPM), Stanvac, and Caltex. Around 1930, BPM owned 85 percent of the oil production; but by the end of the 1930s, this percentage had declined to 55 percent due to heavy competition with Stanvac, which by then owned 30 percent of the promising oil market. In 1938, oil and related products determined an output value of 23.6 percent of the total export, a value of about US $\$ 190$ million. The six million tons of oil produced yearly in the Dutch East Indies accounted for only 2.7 percent of the world's total. ${ }^{21}$ Nonetheless, the Dutch economy depended heavily on the revenues of the oil resources coming from its crown colony.

\section{An Epic Battle for Oil}

Once constructed, the Dutch Indies' petroleum landscape attracted the interest of the expanding Japanese Empire, which was eager to seize the area from its European colonizer and use it for its own purposes. In the event of war, the Netherlands, as one of the smaller 
European powers, would not be able to defend its territory in Europe or its colossal colonial empire overseas. Implicitly, they put their faith in British military protection.

After the German victory over the neutral Netherlands in May 1940, Japan stepped up pressure by sending two missions at ministerial level to Batavia demanding a bigger share of the East Indies' oil export. ${ }^{22}$ During these delicate oil talks, the Dutch government was advised by Jan Carel Baron van Eck (member of the executive board), on behalf of Koninklijke/Shell and Fred Kay of Stanvac. The Dutch did not give way, ignored the Japanese demands, and sent the Japanese delegation home empty-handed. But time was running out. Without doubt, oil was the main quest of the armies of the Japanese Emperor and the reason for the invasion of the Dutch East Indies. Oil was vital for the Japanese war machine, although they had almost no experience and expertise in the industry. The weakness of her war potential lay chiefly in the fact that Japan's home production of natural and synthetic oil amounted to only some 10 percent of the country's annual requirements. Of Japan's oil imports in 1939, about 53 percent came from the US, 38 percent from the Dutch East Indies, and 9 percent from other countries. ${ }^{23}$

Indonesia's oil would quickly become a focus of international conflicts and destruction. Japan had to ensure a means of replenishing her storage tanks. ${ }^{24}$ Tokyo needed yearly at least 7.9 million tons of oil to win their Greater East Asia War. ${ }^{25}$ Sumatra could deliver 5.3 million; so for a long-drawn-out conflict, the Sumatran oil was crucial (Figure 3.10). Therefore, Japanese troops were instructed to put the most important oil centers in their hands quickly without any loss or destruction (Figure 3.11). At the same time, Dutch troops were instructed to destroy the oil facilities before Japanese troops could seize them. Authorities in Batavia had boasted that they had 500,000 tons of oil in storage in Palembang and that if the Japanese forces started to move upriver; they would release 10,000 tons of oil per day into the Moesi River and burn up the Japanese convoy. ${ }^{26}$ The tension was tangible everywhere. The Dutch colony was definitely in peril. ${ }^{27}$

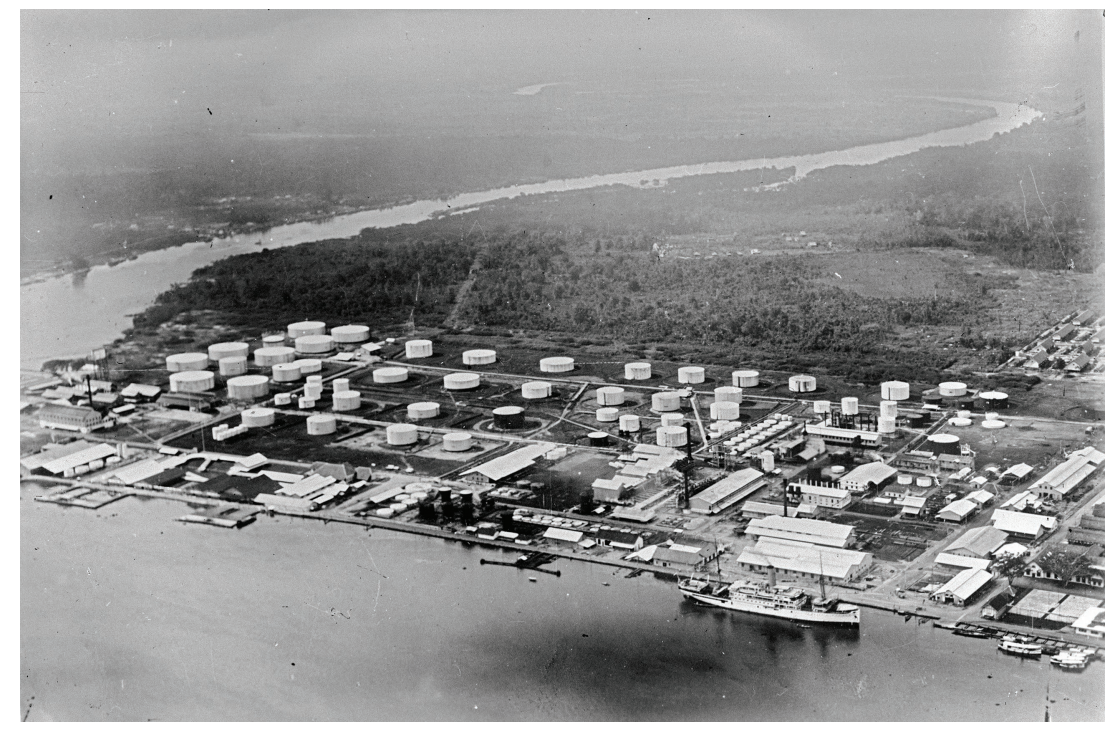

FIGURE 3.10 Aerial photograph of Pladjoe's invaluable and large export refinery, taken around 1930. The two refineries of BPM and Stanvac, being international, were largely independent of local Indonesian conditions. Source: Collection Nationaal Museum van Wereldculturen. Coll. no. 10006848. 


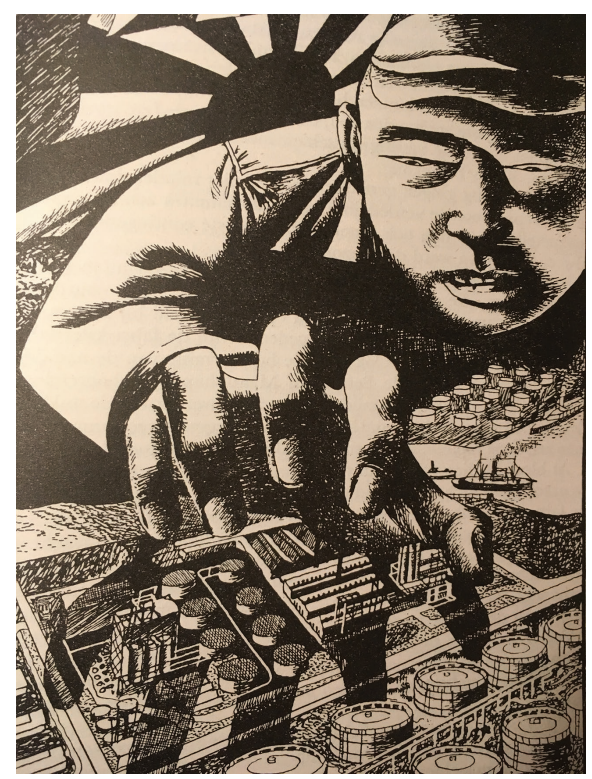

FIGURE 3.11 Japan's need for Palembang's oil. Source: Shell Historical Heritage and Archive, Johan Fabricius, Brandende Aarde.

Meanwhile, after the fall of France, Japan occupied air and naval bases in French Indochina. Immediately, in August 1941, the American President, Franklin D. Roosevelt, announced a total embargo on the export of oil, including a freeze on all bank transfers. Great Britain and the Dutch government-in-exile in London followed with the same retaliatory measures instantly. ${ }^{28}$ On December 8 , a day after the attack on the American navy fleet in Pearl Harbor, Batavia declared war on Japan. One month later, on January 11, 1942, the Japanese Navy conquered the oil island of Tarakan and the oil center of Balikpapan on Borneo. Another month later, on February 14, at the time that the "invincible" British fortress in Singapore was about to fall, a Japanese invasion fleet of some 10,000 men led by Vice Admiral Jisaburõ Ozawa was sailing from Cam Ranh Bay in French Indochina toward South Sumatra. Their operational plan was to seize and secure the oil refineries at Pladjoe and Soengei Gerong and the superior aerodrome Talangbetoetoe, where American B-17 Flying Fortress bombers were temporarily stationed. ${ }^{29}$ In order to secure these sites and halt the frustrating scorched-earth policy, Japan flew in-by complete surprise-over 500 men of the first Paratroop Raiding Group, under Colonel Seiichi Kume. ${ }^{30}$ Prior to the airborne insertion, Japanese aircrafts dropped countless propaganda leaflets over Pladjoe issuing a warning that anyone who set oil fields or refineries on fire would be executed (Figure 3.12). The leaflet had the size of a postcard, and was printed in the Royal Dutch orange color, and written in Dutch, ordering: "Dutchman: protect the oil facilities" (Hollander: Bescherm het petroleum-terrein).

To defend Palembang, there were about 2,000 Dutch troops, plus reinforcements of Australian units and British anti-aircraft sections. The Territorial Command of the Royal Netherlands Indies Army (KNIL), under Lieutenant Colonel Laurens N. W. Vogelesang, 


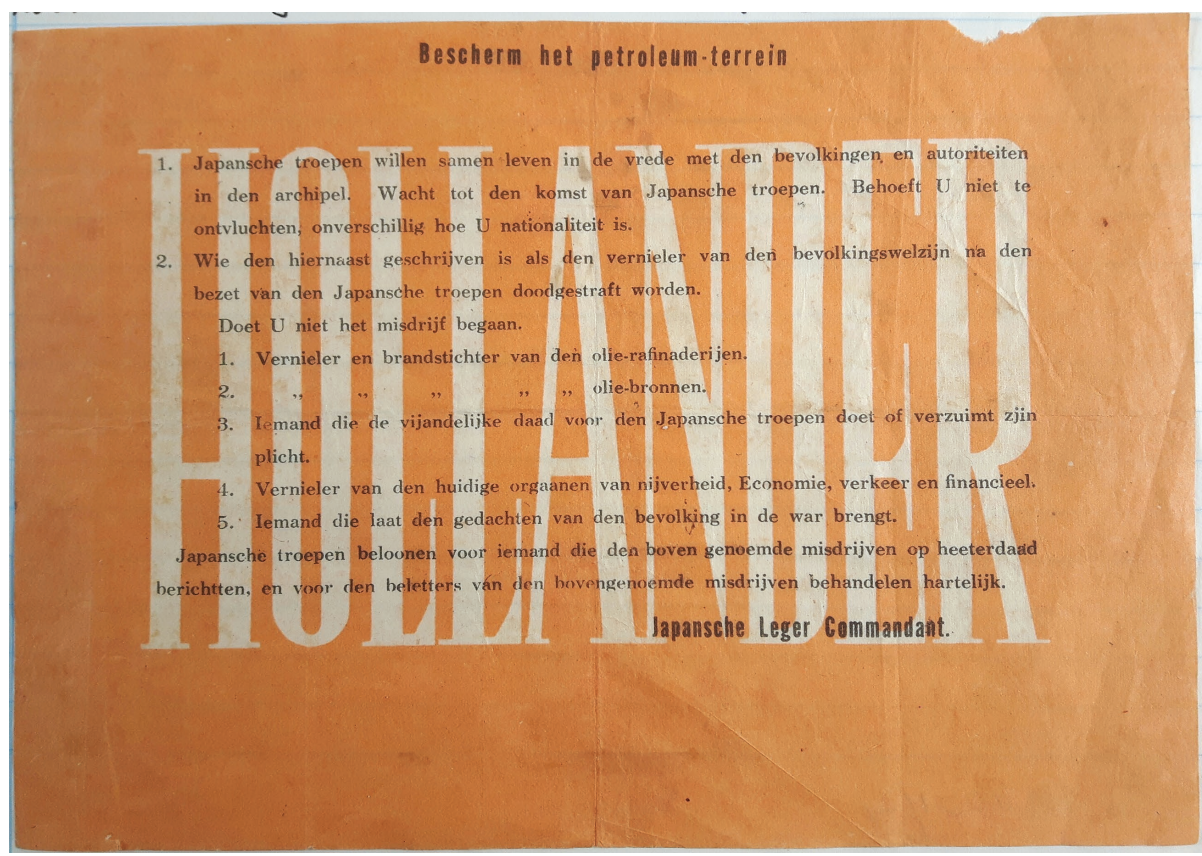

FIGURE 3.12 Airborne leaflet propaganda tried to discourage the Dutch destroying their own oil installations. Source: Collection Museon, The Hague.

wanted to wait as long as possible before destroying the refineries. Influenced by the oil companies, only a limited destruction was planned, keeping the main installation intact. ${ }^{31}$ Suddenly, in the middle of the night of February 15, Vogelesang received orders from the KNIL headquarters in Bandoeng that priorities had shifted and that his military units must demolish the refinery at once. In the rush, huge tanks of oil products were not damaged at all and neither was the refinery. After this half-hearted action, the Dutch army hastily retreated and quietly slipped away in the darkness. ${ }^{32}$ Pladjoe was soon completely in Japanese hands and they managed to put out the fire in the boilers, shut valves, turn cranks, and disarm most of the demolition charges placed in the complex by the Dutch before they were driven out (Figure 3.13). ${ }^{33}$ From this point on, Pladjoe was called "Refinery No. 1" and managed by Nihon Sekiyu (Nippon Oil), and BPM was renamed Dai Ici Seiyuzo. But there was more damage inflicted on the region. In Palembang, the harbor facilities, rubber factories, and warehouses were set ablaze; in Peraboemoelih, drilling sites were destroyed; in Talang Djimar, the wells were nailed shut; and in Djambi, the oil wells were demolished.

The refinery of Soengei Gerong, on the contrary, was successfully defended by Dutch troops. After the order of Vogelesang, military units deliberately destroyed 80 percent of the refinery, including the oil tanks, using a time-delayed demolition charge. ${ }^{34}$ Nevertheless, the damage done to the refineries and machineries as a result of the scorched-earth tactics was easily fixed by a group of Japanese drilling crewmen and oil engineers flown in to complete the work. After six months, production resumed. ${ }^{35}$ 


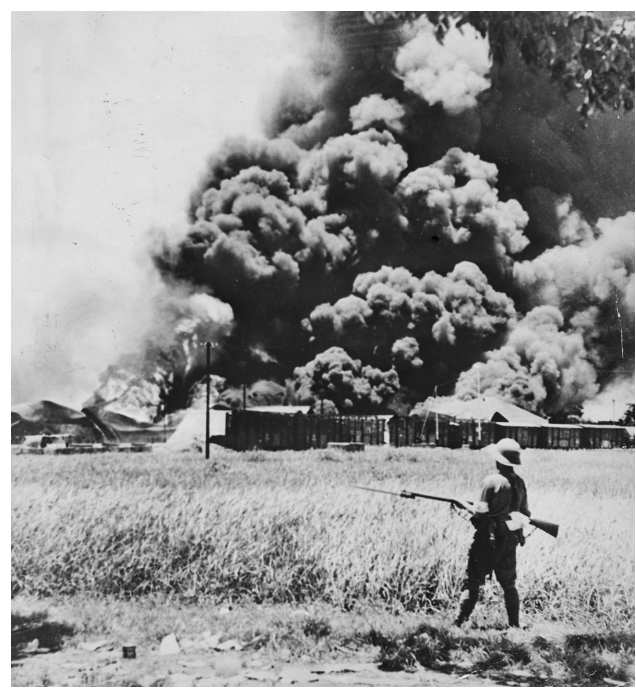

FIGURE 3.13 Japanese soldier watching the burning oil refineries at Palembang, February 15, 1942. Source: Image bank WWII, NIOD, Amsterdam.

\section{Japanese Occupation}

At the start of the Japanese occupation, the oil fields in Palembang fell directly under control of the Japanese military, the 25th Army. In the beginning, they made use of 150 oil company employees and evacuees who were forced to work for them on the refineries for about one year as so-called "Nippon workers." But starting in May 1942, all BPM personnel were sent to prison camps. Thus the Japanese could only rely on local oil personnel who were hardly capable of maintaining the machinery. ${ }^{36}$ As reinforcement, in April 1942 the Japanese brought about 300 oil laborers from Java to work at the refineries, where they were also trained at a newly established oil engineering school. In total, about 1,200 workers went to this school during the Japanese occupation, ${ }^{37}$ stimulating a long-term process of "Indonesianization": the number of foreigners who could be employed by foreign oil companies was reduced and positions once held by foreigners were filled with high potential Indonesian nationalists. ${ }^{38}$ Despite these efforts, the considerable lack of investment and the unprofessional handling of oil obtained from the oil fields led to a dramatic drop in oil production during the war, as the annual reports of the Koninklijke pointed out. Wartime figures of the total crude oil production in the Dutch East Indies still showed a rise in 1942 from 3,250,000 to 6,500,000 metric tons in 1943. But inevitably, a steep decline started in 1944. Production fell to $3,750,000$, in 1945 to 850,000 , and then to 302,000 metric tons in 1946, a historic low. ${ }^{39}$

At the same time, all Dutch symbols, including those of BPM/Shell, were banned and replaced by concepts that conformed to the policy of Tokyo's Greater East Asia Co-Prosperity Sphere, which went beyond the political, and also embraced cultural signs and urban symbols like flags, names of houses, monuments, colonial buildings, railway stations, and streets. In March 1943, the Japanese even allowed a huge rally in Batavia to celebrate the one year anniversary of their victory by pulling a statue of "national hero" Jan Pieterszoon Coen in public space from its plinth. This iconoclastic action was filmed by the Japanese and used as propaganda material afterwards. Moreover, Batavia was renamed Djakarta. For safety 


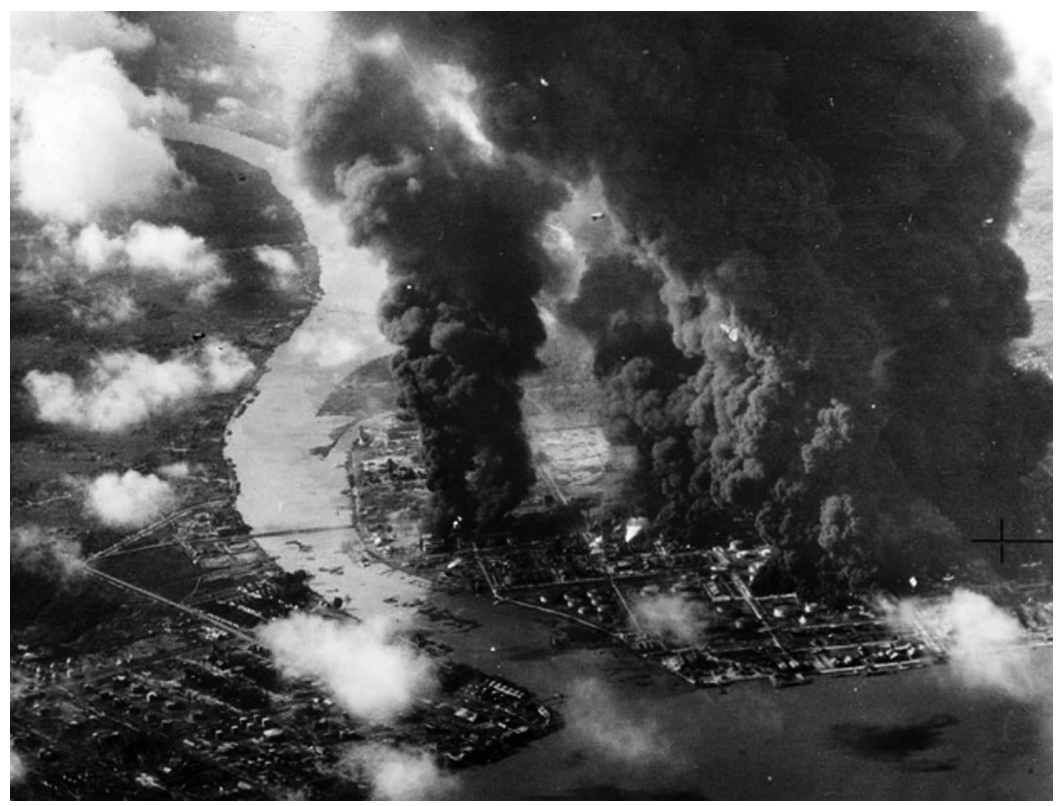

FIGURE 3.14 Pladjoe burning after the "Meridian I" attack by British Royal Navy aircrafts on January 24, 1945. The more compact refinery of Soengei Gerong, the target of the follow-up "Meridian II" strikes on January 29, sits in the bottom-left of the picture with the Komerine River separating the two. Source: www.armouredcarriers.com.

reasons, Shell moved its headquarters to Curaçao in the Caribbean. Immediately, the Japanese Propaganda Corps took over the empty BPM head office in the city center.

In November 1943, about 2,000 Dutch, Dutch Indies, and British prisoners of war and conscripted laborers from Java or rõmosha (economic soldiers) were forced to load ships with oil and work relentlessly on the construction of two new airfields on remote areas covered in dense vegetation around Palembang. The first was in Betoeng/Ketiau, about $75 \mathrm{~km}$ southwest of Palembang, and was intended to replace the war-damaged Dutch airfield P1 (Talangbetoetoe/Kenten). Construction on the second airfield began in May 1944 in Pangkalan Balai, about $40 \mathrm{~km}$ northwest of Palembang, and it replaced P2, the strategic Dutch airfield near Peraboemoelih. ${ }^{40}$ At least 20 percent of the men died during construction work. ${ }^{41}$

At the end of the Pacific War, massive Allied bombardments started on Palembang and its oil refineries. First, the attack by American B-29s in the night from August 10 to 11, 1944, was launched all the way from Ceylon (Sri Lanka), but with negligible effect. Only a single building was destroyed, but mines dropped in the river sank three Japanese ships, preventing oil from being transported for a month. Plans were adapted, and in January 1945, a more precise series of British air strikes were undertaken on the Japanese-held twin refineries that were supplying at that time half of Japan's oil and three quarters of their aviation fuel (Figure 3.14). As a result, columns of thick black smoke rose 10,000 feet for days. Along with these "Palembang Raids" that diminished oil production, Japanese oil tankers were constantly attacked, which had a tremendous effect on the Japanese ability to transport oil to Japan. These collective Allied efforts eventually brought Japan's war machine to a halt. ${ }^{42}$ 


\section{Recapturing the Oil Facilities}

During the brief interlude of Japanese control, the Indonesian nationalist movement had gained in power. Nationalist leaders, pressed by zealous Indonesian youth groups (pemoeda), seized the opportunity created by the unexpected Japanese surrender signed on August 15, 1945. On August 17, 1945, two days after Japan's unconditional surrender, 300,000 Japanese troops in Indonesia took note as two prominent nationalist leaders Achmad Soekarno and Dr. Mohammed Hatta proclaimed the independent Republic of Indonesia unilaterally. This revolutionary action prevented the oil installations from automatically falling back into Dutch hands. The British/Allied supreme command, led by General Sir Philip Christison, realized that the Indonesian people were fighting for their own cause and issued a statement that implied a de facto recognition of the republic. As a consequence, no Dutch troops were allowed to land and reconquer the former colony.

Meanwhile, the situation at the oil fields was complicated. At the request of the Allied forces, the refineries at Pladjoe and Soengei Gerong were temporarily put under the supervision of Japanese soldiers in September 1945. They had to occupy these oil installations, including the nearby oil fields, in order to prevent the freedom fighters from destroying the oil wells. All the other oil fields in South Sumatra were taken over by the Indonesian forces. On the spot, Indonesian (oil) freedom fighters (lasjkar minyak) quickly founded their own semi-militarized oil workers association: Persatoean Pegawai Minyak (PPM). This initiative came from Dr. Adnan Kapau Gani and Dr. Mohammad Isa, who both held prominent seats in the regional government of the republic in Palembang. ${ }^{43}$

Far away in London, the CEO of the Koninklijke, Dr. Barthold T. W. van Hasselt, watched the nationalist developments with alarm. He was eager to start the reconstruction of the refineries and make money again, like in the old days. ${ }^{44} \mathrm{He}$ tried to convince the British and Dutch military command of the enormous interests at stake in the oil business. ${ }^{45}$ In his opinion, the (former) Japanese troops should be replaced by British troops. He needed at least 4,000 men to protect the oil installations, but they were not available, because the spearhead of the military operation was on Java. Apparently, the British were not inclined to help the Dutch. ${ }^{46}$

Then something remarkable happened. Gani, the Republican Governor of South Sumatra, proposed that BPM itself should take the oil centers back from Japanese control as quickly as possible. ${ }^{47} \mathrm{He}$ wanted two things in return. First, BPM had to pay the republic interest on its profits. ${ }^{48}$ Second, all the Indonesian workers that were occupying the refineries at that moment should be hired by BPM and paid with food, textiles, and household items $^{49}$ (Figure 3.15). This was a profitable oil deal, because through this peaceful consultation and smart oil diplomacy, at the end of September 1946, the republic gained the international recognition they urgently needed, and a confident BPM succeeded in regaining control of their most valuable oil installations without the assistance of either the Dutch government or the army. ${ }^{50}$ As a bonus, "trade-soldier" Gani hoped to consolidate his political base and improve his own economic position. ${ }^{51}$ Soon, 3,600 laborers were back at work at the refineries.

Nevertheless, truce and peace were elusive. The situation escalated in the end of October after an inflammatory speech by Republican General Raden Soedirman. The Republican revolt was reverted and led on New Year's Day 1947 to heavy bombing of Palembang by combined Dutch navy and air force units. This punitive strike was undertaken without any 


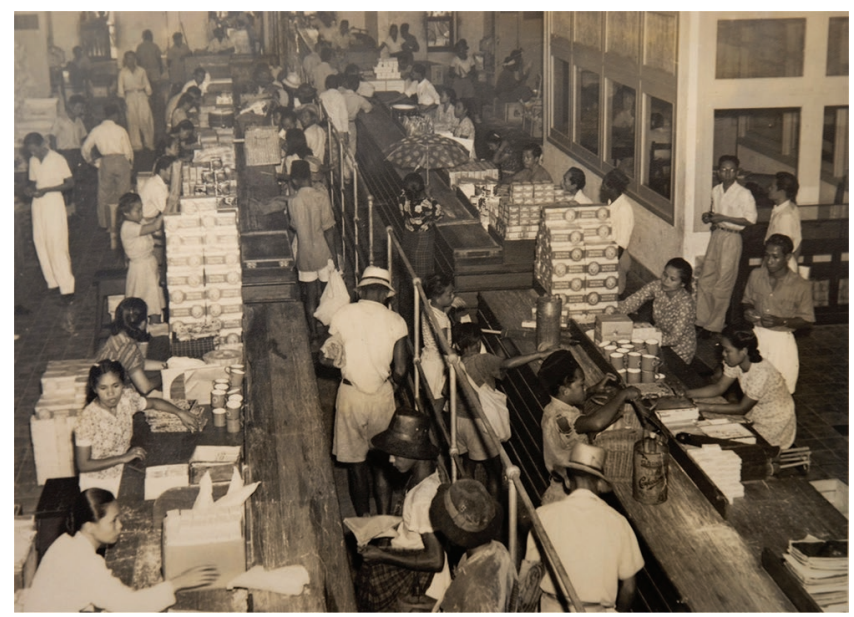

FIGURE 3.15 Laborers did their shopping in the so-called Land Civo on the Pladjoe compound, 1948. Source: Collection Ruud Spangenberg.

notice or warning, causing many civilian losses and leaving the city center in ruins. ${ }^{52}$ After this "Battle of Five Days and Five Nights" in the city heart of Palembang, Republican troops were forced to withdraw to a radius of $20 \mathrm{~km}$ around the petroleum city. Subsequently, their political leaders fled and joined the radical camp in the Djambi area. Economic occupation and military warfare followed in rapid succession.

\section{Operation Product}

After the landing of Dutch troops in March 1946, progressive Dutch Lieutenant Governor General Dr. Hubertus van Mook in Batavia and several politicians from the then-cabinet Beel in The Hague became more amenable to the oil interest in South Sumatra and they were increasingly inclined to intervene. The First Dutch Offensive (Agresi Militer Pertama or Eerste Politionele Actie) soon followed in July-August 1947 and was appropriately named "Operation Product." The main goal was to occupy the vital economic areas as soon as possible and restart the main companies. Moreover, there was plenty of work for the tens of thousands of people in the overcrowded areas. In this way, an important recruitment basis for the Indonesian freedom fighters would disappear. In fact, the mission would lead to better working conditions, would diminish the chance of industrial strikes, and would increase oil production (Figure 3.16).

The Dutch Y-Brigade led by the hotheaded Colonel Frits Mollinger had to occupy the key oil centers around Palembang that were occupied by the Republicans. From a military and economic point of view, this concerted campaign was a success. By mid-August a substantial recovery of the oil production was realized - the refineries were once again receiving oil from the oil fields and would work their way up to 2.5 million barrels per day. ${ }^{53}$ During military operations, small units of BPM technicians were operating on the heels of the Dutch forces in order to reboot oil extraction in the recaptured areas as soon as possible. ${ }^{54}$ The Second Dutch Offensive in December 1948 had hardly any effect on oil production at Pladjoe. BPM's crown jewel was functioning at full speed. Postwar figures of 


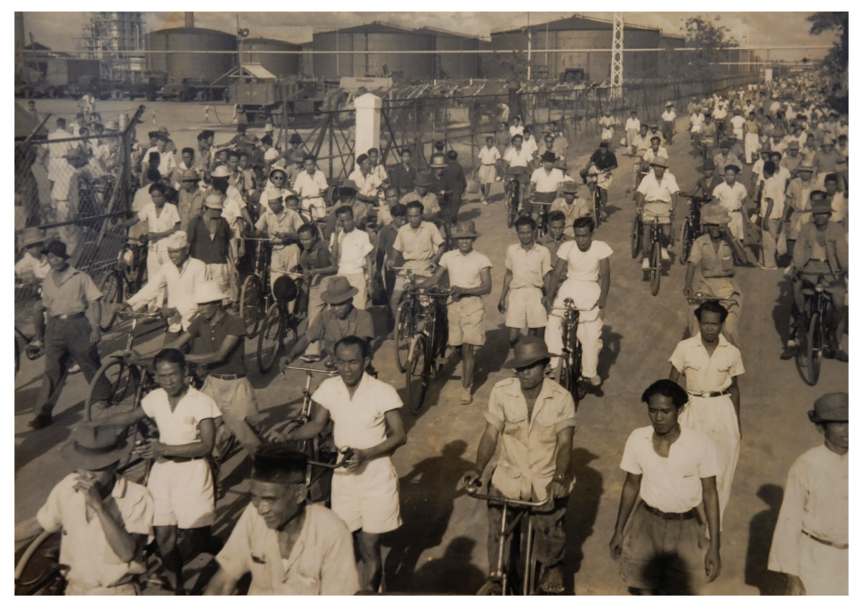

FIGURE 3.16 Indonesian workers on the Pladjoe plant go home after work, 1948. Source: Collection Ruud Spangenberg.

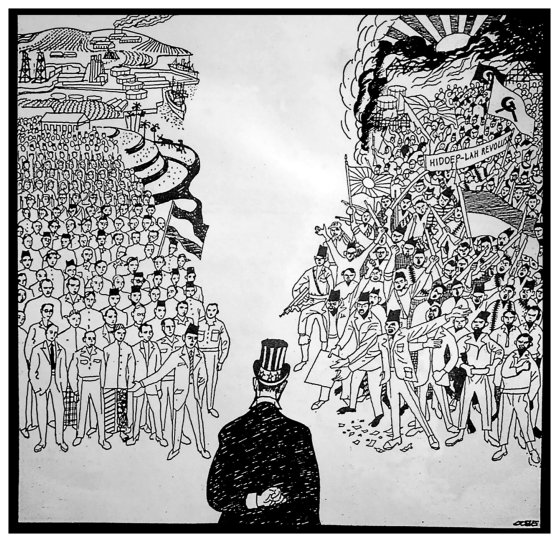

FIGURE 3.17 The Choice. Uncle Sam, the US, had to choose between the political picture drawn on the left side, where continuity, colonialism, prosperity, order, and full oil tankers were omnipresent; and that on the right side, where revolution, chaos, burning oil installations, and waving Republican and communist flags prevailed. Source: Elseviers Weekblad, 16 August 1947.

the total crude oil production in the Dutch East Indies showed a sharp rise: although the production was in 1946 still 302,000 metric tons, in 1947 it was already 1,115,000, in 1948 4,326,000, in $19495,930,000$, and in 1950 it had reached the prewar level of $1938 .{ }^{55}$

Ironically, the Dutch military successes were a pyrrhic victory, because they caused US support to shift to the republic and forced the Dutch to negotiate the transfer of sovereignty to Indonesia. The US tried on an anticolonial attitude and pressured the Dutch government to recognize the Indonesian cry for freedom. The US played their joker card. At the time, they were funding the costly reconstruction of postwar Europe, including the Netherlands. So, if the Netherlands refused to cooperate and kept on fighting the republic, they would risk the promised annual revenues of the US-sponsored Marshall Plan (Figure 3.17). 
At the same time, there was a housing shortage and a large demand for adequate housing for military units in Palembang. BPM and Stanvac, as corporate enterprises, wanted to help out the colonial state, for once. They gave up between fifty and sixty European houses to the Dutch army in order to protect Palembang against Republican forces. Moreover, the BPM built fourteen permanent and sixteen nonpermanent European-style houses, two apartment blocks for forty bachelors, and twenty-seven extra hotel rooms. In return, the central government invested half a million dollars in building fifty houses in the elite neighborhood of Talang Semoet. ${ }^{56}$

\section{Oil Diplomacy}

In the beginning of 1948, the management of BPM, including Johan Frederik van Diermen, the headstrong administrator of Pladjoe, was exploring the possibilities for regaining control of the oil fields near Djambi. In a secret report addressed to Prime Minister Dr. Louis Beel, BPM did not demonstrate support for a military action against Djambi for fear of damage to and sabotage of the oil installations. Instead, BPM paid US $\$ 5,000$ to Republican security forces of the oil fields and installations near Djambi in order to prevent destruction. ${ }^{57}$ BPM pragmatically went one step further, and in May 1948 began direct negotiations with the moderate leaders and "oil barons" Isa, Sutowo, Gani, and Pattiasina, who had fled to Djambi after the earlier battle around Palembang. As a result of these "peace talks," the vital oil concessions fell back into Dutch control. BPM staff was relieved, but Van Diermen's conduct led to outrage at the headquarters of the Koninklijke in The Hague and among the staff of Stanvac, as they were not informed at all. ${ }^{58}$ This was not the first time BPM had engaged in such covert dealings; it had happened before with the Gani deal at Pladjoe. The Minister on Overseas Territories Lubbertus Götzen informed the prime minister right away and told him that "Van Diermen could not care less who has the supreme authority, if only he gets oil." 59

At times during the Cold War, BPM became convinced that communism might get a foothold in the Indies and they might lose their monopoly position once again. Van Diermen wrote several letters to the Dutch prime minister to share his concern. One synopsis concluded:

the red peril is now prevailing all over the world, and the power of international communism is expanding to the South East Seas. If the third world war should break out, Soviet Russia will occupy South East Asia. To prevent that peril, now is the time. ${ }^{60}$

Directly after the landing of Dutch paratroopers on December 29, 1948 and January 5, 1949-performing a heavy-handed action-rebels caused severe damage to the NIAM oil fields near Rengat and Air Molek. This sabotage action was executed despite the Van Diermen deal with the Republicans and was carried out by separatist groups striving for independence; the Indonesian revolution was full of regional dynamics. BPM staff had predicted the destruction in many conversations with Dutch politicians. ${ }^{61}$ However, both BPM and Dutch politicians were in favor of recapturing this important oil center. ${ }^{62}$ Not least, because the US oil company A. S. Cowie \& Co., Inc. located in California was eager to buy local concessions that were now in the hands of the republic for US $\$ 1$ million. ${ }^{63}$ During the military action, small technical BPM units operated again as "advance parties" 
in the slipstream of the Dutch troops and were able to minimize the damage and start repairing works. ${ }^{64}$ Back in Dutch hands by mid-1949, crude oil was being piped again at prewar production levels.

Remarkably, in their effort to safeguard the oil business and restore the prewar situation of peace and prosperity, BPM's captains of industry, Dutch army commanders, and politicians in both Batavia/Jakarta and The Hague worked closely together, constantly using oil as a military weapon, since it was needed directly to fuel military operations in Asia. It was obvious that European managers of the oil refinery, the central Republican government, and the local government of Palembang all had an interest in this oil company town. As a result, they were constantly in conflict with each other.

With the advent of Indonesian independence in December 1949, the balance was drawn. It was clear that BPM could not do business the way it had before the war. Pladjoe and its infrastructure was saved from total destruction, but Djambi was regained only in 1949 and the refinery in Pangkalan Brandan in North Sumatra, the origin of Royal Dutch/Shell Group, was lost forever due to fierce local resistance in the northern province of Atjeh. Despite this outcome, postwar oil production would eventually triple, compared to the prewar average. ${ }^{65}$

In the beginning of the 1950s, the need for road renovation and construction in the war-damaged city of Palembang was more urgent than ever, especially in the Hoeloe area, which had been heavily damaged during the war and the revolution. In 1950, the municipality implemented a reconstruction plan, designed by Dutch architect Hans Lüning, which was an adaptation of the town plan of Thomas Karsten dating from 1937.

In the mid-1950s, when anti-Dutch sentiments prevailed in postcolonial Indonesia, political leaders in Jakarta decided not to nationalize BPM, unlike more than 700 other Dutchowned enterprises and industries, a decision made because the company was "indispensable" to the Indonesian economy and because of BPM's combined Anglo-Dutch ownership. ${ }^{66}$ Subsequently, Europeans who worked in the oil refinery continued to play a leading role in the postindependence period. Finally, in December 1965, when the political situation in Indonesia was rather tense, Koninklijke/Shell pulled out by selling all rights of exploration and production for US\$110 million to Pertamina. ${ }^{67}$ Once again, this was a clever oil deal, and besides, Shell would return soon.

\section{Conclusion}

This concise history illuminates how, from the 1920s on, the South Sumatran city of Palembang with its harbor and perfect river infrastructure gained new importance from the booming oil industry and the growth of a petroleumscape. In relative isolation, Pladjoe could expand and modernize undisturbed, in part because of the continued presence and rule of Western managers. After the corporate battle with competitors, like Stanvac and Caltex in the 1920s and 1930s, the battle for "black gold" with diplomatic means followed, and finally a military battle for oil was fought in the 1940s.

While oil attracted military conflict, the goal of the invader was to keep production going. It aimed to inflict little destruction and rebuild quickly. The presence of a global or multinational company interested in the space, with funding from other parts of the world, facilitated this process. While these sites were fought for halfway around the world, the armies also made sure that production continued. They depended on the sites and made sure 
that they were rapidly rebuilt when damaged. While foreign governments had to abandon their oil structures and territories, the major companies continued to work across borders. The presence of the oil infrastructure effectively guaranteed the continuation of the carefully built palimpsestic petroleumscape.

\section{Notes}

1 Carola Hein, "Oil Spaces: The Global Petroleumscape in the Rotterdam/The Hague Area," Journal of Urban History 44, no. 5 (September 2018): 887-929.

2 H. Gabriëls, Koninklijke Olie: de eerste honderd jaar 1890-1990 (The Hague: Shell, Den Haag, 1990), 9-18; Frederik Carel Gerretson, History of the Royal Dutch, Vol. 1 (Leiden: Brill, 1973), 58-59; J. Ph. Poley, Eroïa, the Quest for Oil in Indonesia (1850-1898) (Netherlands: Springer, 2000), 82.

3 Joost Jonker and Jan Luiten van Zanden, A History of Royal Dutch Shell: Vol. 1 (New York: Oxford University Press, 2007), 23; Keetie E. Sluyterman, Kerende kansen. Het Nederlandse bedriffleven in de twintigste eeuw (Netherlands: Boom, 2003), 53-54.

4 Woonkyung Yeo, "Palembang in the 1950s: The Making and Unmaking of a Region" (PhD diss., University of Washington, 2012), 79-80; Anderson G. Bartlett a.o., Pertamina: Indonesian National Oil (Jakarta: Amerasian Ltd, 1972), 48.

5 Frederik Carel Gerretson, History of the Royal Dutch, Vol. 2 (Leiden: Brill Archive, 1958), 39-64.

6 Carola Hein, "Between Oil and Water. The Logistical Petroleumscape," The Petropolis of Tomorrow, eds. Neeraj Bhatia and Mary Casper (New York: Actar/Architecture at Rice, 2013), 436-47.

7 Ida Liana Tanjung, "The Indonesianization of the Symbols of Modernity in Plaju (Palembang), 1930s-1960s," in Cars, Conduits, and Kampongs: The Modernization of the Indonesian City, 19201960, eds. Freek Colombijn and Joost Coté (Leiden: Brill, 2015), 302.

8 Freek Colombijn, Under Construction, The Politics of Urban Space and Housing During the Decolonization of Indonesia, 1930-1960 (Leiden: KITLV Press, 2010), 80, 126; Idaliana Tanjung, "Plaju, Kota Minyak di Ulu Palembang simbol pribumi vs modernitas," 39, Paper Seminar on "Street Images: Decolonization and Changing Symbolism of Indonesian Urban Culture between 1930s and early 1960s," Yogyakarta, August 8-9, 2005.

9 Peter J. M. Nas, "Palembang: The Venice of the East," Issues in Urban Development: Case Studies from Indonesia, ed. Peter J. M. Nas (Leiden: CNWS, 1995), 133-34, 140; Ben de Vries, "Epische strijd om Indische olie," Elsevier, 26 March 2016, 80-83; Ben de Vries, "Demi Minyak Hindia, Riwayat De Bataafsche Petroleum Maatschappij, pendahulu Shell, yang sukses mengambil minyak di hindia Belanda sampai akhir era 1940-an," Historia 32, tahun III (October 2016): 34-37.

10 Nieuwe Rotterdamsche Courant, 19 June 1924, and Het Vaderland, 29 May 1924, 19 June 1924, and 13 July 1924; V. Hediger and P. Vonderau, eds. Films that Work. Industrial Film and the Productivity of Media (Amsterdam: Amsterdam University Press, 2009), 243-53; G. A. Jansen Hendriks, "Een voorbeeldige kolonie: Nederlands-Indië in 50 jaar overheidsfilms, 1912-1962” (PhD diss., University of Amsterdam, 2014), 62-63.

11 Johan Fabricius, Brandende Aarde or East Indies Episode: An Account of the Demolitions Carried Out and of some Experiences of the Staff in the East Indies Oil Areas of the Royal Dutch-Shell Group During 1941-1942 (London: Shell Petroleum Co., 1949), 98-99; Mestika Zed, Kepialangan, Politik, Dan Revolusi: Palembang 1900-1950 (Jakarta: Pustaka LP3ES Indonesia, 2003), 77-79.

12 Pauline Dublin Milone, Urban Areas in Indonesia: Administrative and Census Concepts (Berkeley: University of California Press, 1966), 108-39; W. J. W. Wellan, "De Stad Palembang in 1935: Tweehonderdvijfenzeventig Jaar Geleden, als een Phoenix uit haar Asch Herrezen," Koloniaal Tijdschrift, 24, no. 3 (1935), 232.

13 Ida Liana Tanjung, "Indonesianization," 306.

14 Hein, "Oil Spaces," 888, 897-901.

15 Elsbeth Locher-Scholten, Sumatran Sultanate and Colonial State Jambi and the Rise of Dutch Imperialism, 1830-1907 (Ithaca, NY: Southeast Asia Program, Cornell University, 2004), 280-81, 309.

16 L. J. Touwen, "Voordeel van veelzijdigheid. De economische ontwikkeling van Palembang en Djambi tussen 1900 en 1938," Economisch en Sociaal-Historisch Jaarboek 54 (1991): 154-55, 177. 
17 Agus Setiawan, "The Political and Economic Relationship of American-Dutch Colonial Administration in Southeast Asia: A Case Study of the Rivalry between Royal Dutch/Shell and Standard Oil in Netherlands Indies (1907-1928)" (PhD diss., SHSS Bremen, 2014), 3-4, 40-41.

18 Bartlett et al., Pertamina, 48-49.

19 Hiroyoshi Kanō, Indonesian Exports, Peasant Agriculture and the World Economy, 1850-2000 (NUS Press, 2007), 226-27, 230.

20 Alex Hunter, “The Indonesian Oil Industry," The Economy of Indonesia: Selected Writings, ed. Bruce Glassburner (Ithaca, NY: Cornell University Press, 1971), 256-57.

21 H. Baudet and M. Fennema, Het Nederlandse belang bij Indië (Utrecht-Antwerpen: Het Spectrum, 1983), 158.

22 Fabricius, East Indies Episode,14; Loe de Jong, Het Koninkrijk der Nederlanden in de Tweede Wereldoorlog, Vol. 11a (RIOD, 's-Gravenhage/Staatsuitgeverij 1985), 692; Stephen Howarth and Joost Jonker, A History of Royal Dutch Shell: Vol. 2 (New York: Oxford University Press, 2007), 17, 63; Willem Remmelink, The Operations of the Navy in the Dutch East Indies and the Bay of Bengal, Compiled by the War History Office of the National Defence College of Japan. Senshi Sõsho (War History Series), Vol. 26 (2018) (Leiden: Leiden University Press), 4-14; Gene Eric Salecker, Blossoming Silk Against the Rising Sun: U.S. and Japanese Paratroopers in the Pacific in World War II (Mechanicsburg, PA: Stackpole, 2011).

23 De Jong, Het Koninkrijk, Vol. 11a first half, 507.

24 C. van den Hoogenband and L. Schotborgh, Nederlands-Indië Contra Japan, Deel VI: De Strijd Op Ambon, Timor En Sumatra (Departement Van Defensie, Hoofdkwartier Van De Generale Staf, Krijgsgeschiedkundige Afdeling, 1959); Lionel Wigmore, The Japanese Thrust. Australia in The War of 1939-1945, Vol. IV (Canberra: Australian War Memorial, 1957). The Japanese dilemma, part 1, 11, The Road to War, from Second World War Official Histories.

25 De Jong, Het Koninkrijk, 11a first half, 507; De Jong, Het Koninkrijk, 11a second half, 694-95.

26 Willem Remmelink, The Invasion of the Dutch East Indies. Compiled by the War History Office of the National Defense College of Japan. Senshi Sōsho (War History Series), Vol. 3 (2015), 270.

27 Herman Theodore Bussemaker, "Paradise in Peril. Western Colonial Power and Japanese Expansian in South-East Asia, 1905-1941" (PhD diss., University of Amsterdam, 2001), 754.

28 Online article on dutcheastindies.webs.com/DEI_oil.html, "Japan's Need for Oil and the Embargo (1940-1941)," Fabricius, East Indies Episode, 16-18; De Jong, Het Koninkrijk, 11a second half, 695-96, 702 .

29 De Jong, Het Koninkrijk, 11a second half, 655; J. J. Nortier, "De gevechten bij Palembang in februari 1942," Militaire Spectator (1985): 312; Loe de Jong, The Collapse of a Colonial Society: The Dutch in Indonesia during the Second World War (Leiden: KITLV Press, 2002), 286, 388-89.

30 Erwin Langewis, "Hoe de Japanners de Indische archipel veroverden, 75 jaar geleden: Java zit in de Japanse val," Historiek.net, 23 February 2017; Johannes Jan Nortier, P. Kuijt, and Petra M. H. Groen, De Japanse Aanval op Java: Maart 1942 (1994); Remmelink, Invasion, 288-89, 316, 329; De Jong, Collapse, 35.

31 Howarth and Jonker, Royal Dutch Shell, 65-66.

32 Gene Eric Salecker, "Deadly Dash Forward, Japanese Parachute Forces Mounted an Assault on the Island of Sumatra soon after Pearl Harbor," WWII History (October 2016): 49.

33 Remmelink, Invasion, 329-30; David van Reybrouck, Revolusi (De Bezige Bij. Amsterdam (2020), 167-68.

34 Fabricius, East Indies Episode, 105-6, 120-25; Peter Keppy, Sporen van Vernieling: Oorlogsschade, Roof en Rechtsherstel in Indonesië 1940-1957 (Amsterdam: Boom, 2006), 42-43; J. J. Nortier, "De aanval op Palembang in februari 1942”, Militaire Spectator, part 2 (1985), 361; Remmelink, Invasion, 344.

35 De Jong, Het Koninkrijk, Vol. 11a, first half, 677; J. J. Nortier, "Japanese parachutisten, Samoerai van de Tweede Wereldoorlog," Militaire Spectator (1983): 152, 519-23; Remmelink, Invasion, 284.

36 Jean Aden, "Oil and Politics in Indonesia 1945 to 1980" (PhD diss., Cornell University, 1988$), 40$.

37 Bartlett et al., Pertamina, 56-57; De Jong, Collapse, 50.

38 J. Thomas Lindblad, "Van Javasche Bank naar Bank Indonesia. Voorbeeld uit de praktijk van indonesianisasi," Tijdschrift voor Sociale en Economische Geschiedenis 1 (2004): 28-46; "The Importance of Indonesianisasi during the Transition from the 1930s to the 1960s," Itinerario 26, no. $3 / 4$ (2002): 51-71.

39 Hunter, Indonesian Oil Industry, 259, 266. 
40 J. van Dulm a.o., Geillustreerde Atlas van de Japanse Kampen in Nederlands-Indië 1942-1945 (Torino, Italy: Asia Maior, Purmerend, 2001), 74-79.

41 Loe de Jong, Het Koninkrijk, Vol. 11b, second part ('s-Gravenhage/Staatsuitgeverij), 694-95.

42 Howarth and Jonker, Royal Dutch Shell, 69.

43 Bartlett et al., Pertamina, 71-73.

44 Howarth and Jonker, Royal Dutch Shell, 226-28.

45 Archief Indonesië in overgangstijd. Overgekomen archieven uit Batavia. Algemene Secretarie (AS), 2e Afdeling, no. 3503, 12 April 1946. National Archives (NA), The Hague.

46 Collectie Nederlands-Indië 1945-1950, Sumatra, 207-I, 23 October 1946. Archive Netherlands Institute Military History (NIMH).

47 Collectie Nederlands-Indië 1945-1950, Sumatra, 207/A, nota situatie Palembang, ondertekend 27 August 1946, NIMH.

48 Aden, "Oil and Politics," 70-71.

49 Secretaris-generaal Overzeese Gebiedsdelen aan Lt. G-G, 24 August 1946. AS, number 3503. NA.

50 Bartlett et al., Pertamina, 73-74; Ida Liana Tanjung, 312-13; Yeo, “Palembang,” 84-86.

51 Bambang Purwanto, "Economic Decolonization and the Rise of Indonesian Military Business," Indonesian Economic Decolonization in Regional and International Perspective, eds. J. Thomas Lindblad and Peter Post (Leiden: KITLV Press, 2009), 44-46.

52 Anne-Lot Hoek, "De verzwegen moorden van Palembang. Geschonden oorlogsrecht," Vrij Nederland, September 2017, 42-49; Zed, Palembang 1900-1950, 110.

53 Annual Report (Jaarverslag) of the Koninklijke, 1947.

54 Collectie Nederlands-Indië 1945-1950, Sumatra, 207/4, December 1948, NIMH.

55 Hunter, Indonesian Oil Industry, 259.

56 Colombijn, Under Construction, 259-60, 341-43.

57 Directeur van het kabinet G-G aan Lt. G-G, 2 August 1947, AS, no. 3505, NA; Locher-Scholten, Sumatran Sultanate, 287.

58 Götzen aan minister-president Beel, 26 May 1948. Rijks Geschiedkundige Publicatiën (RGP) XIII, no. 319.

59 Minister zonder portefeuille Götzen aan Beel, 7 June 1948. RGP XIV, no. 12.

60 Archief Indonesië in overgangstijd. Overgekomen archieven uit Batavia. AS, no. 353.83.1.329.15. Synopsis, part 1, 19 June 1948, "Het communisme in de Indonesische Republiek". Part 2: "Internationale aspecten en Kominform," NA. Indonesian leaders surpressed a communist revolt in Madioen (East Java) on 18 September 1948.

61 Ibid.; Locher-Scholten, Sumatran Sultanate, 287-92.

62 Notulen van vergadering gehouden ten huize van de legercommandant op 20 September 1948. RGP XV, 138.

63 Chef directie Verre Oosten te Batavia (Elink Schuurman) aan ambassadeur te Washington Van Kleffens en minister van Buitenlandse Zaken Van Boetzelaer van Oosterhout, 1 May 1948, RGP XIII, no. 230 .

64 Collectie Nederlands-Indië 1945-1950, Sumatra, 207/4, December 1948, ondertekend door algemeen commandant Operatie Ekster, NIMH; Petra M.H. Groen, Marsroutes en dwaalsporen. Het Nederlands militair-strategisch beleid in Indonesië 1945-1950 (1991), 143.

65 W. Brand, "Heroriëntatie van vroeger in Indonesië werkende Nederlandse bedrijven," in Handelswereld en wereldhandel, ed. H. Baudet (Rotterdam: Honderd jaren Internatio, 1963), 170.

66 Henk Biersteker, "Hoe Shell uit Indonesië verdween," Hervormd Nederland, 29 July 1995, 51; Gabriëls, Koninklijke Olie, 171; Aden, "Oil and Politics," 177.

67 Howarth and Jonker, Royal Dutch Shell, 240; J. Thomas Lindblad, Bridges to New Business. The Economic Decolonization of Indonesia (Leiden: KITLV Press, 2008), 159; Khong Cho Oon, The Politics of Oil in Indonesia: Foreign Company-Host Government Relations (Cambridge: Cambridge University Press, 1986), 138-39; Sluyterman, Kerende kansen, 219. 